\title{
Antithrombotic therapies for elderly patients: handling problems originating from their comorbidities
}

This article was published in the following Dove Press journal:

Clinical Interventions in Aging

\author{
Masahisa Arahata \\ Hidesaku Asakura \\ Department of Hematology, Graduate \\ School of Medicine of Kanazawa \\ University, Kanazawa, Ishikawa, Japan
}

\begin{abstract}
Compared with younger people, elderly people have higher risks for both thrombosis and bleeding. Furthermore, comorbidities frequently found in elderly patients complicate the management of antithrombotic therapy. Thus, when treating these patients, physicians often find it difficult to incorporate the principles of evidence-based medicine and must determine the best treatment option for each patient. Recently, in the fields of cerebrovascular and cardiovascular diseases, researchers have been rapidly accumulating new data regarding antithrombotic therapy, particularly in the areas of direct oral anticoagulants (DOACs) and dual antiplatelet therapy (DAPT). However, information related to elderly patients receiving antithrombotic therapy is still relatively limited. There are also more and more publications describing how antithrombotic therapy affects the pathogenesis of non-thrombotic diseases. Similarly, the number of reports concerning adherence to this therapy has been increasing lately. However, no review articles detailing these findings have yet been published. In actual clinical practice, antithrombotic therapy in the elderly is not a treatment strategy targeted to only one organ or disease. Rather, it requires an interdisciplinary approach aimed at maintaining the overall health of the patient. Thus, to assist physicians' decision-making processes for elderly patients, an overview of recent findings related to the evidence regarding concomitant medications, the secondary benefits of antithrombotic therapy for patients with comorbidities, and evidence regarding medication adherence is provided.
\end{abstract}

Keywords: antithrombotic therapy, dual antiplatelet therapy, direct oral anticoagulants, elderly patients with comorbidities, medication adherence

\section{Introduction}

Antithrombotic treatment in the chronic phase of cardiovascular diseases consists mainly of oral anticoagulant and antiplatelet agents. ${ }^{1}$ Anticoagulant agents inhibit the coagulation cascade and fibrin formation. ${ }^{1}$ They are used mainly for primary or secondary prevention of embolic events (and their causes) such as cardiogenic cerebral embolism (and atrial fibrillation), ${ }^{2,3}$ pulmonary embolism (and deep vein thrombosis), ${ }^{4}$ and following heart valve replacement. ${ }^{5}$ Antiplatelet agents inhibit clot formation by preventing platelet activation and aggregation. ${ }^{6}$ They are mainly used for primary or secondary prevention of arterial thrombosis at area of arteriosclerotic changes, such as in non-cardiogenic ischemic stroke, ${ }^{7}$ angina pectoris, ${ }^{6}$ and peripheral artery diseases (PADs). ${ }^{1}$ These anticoagulant and antiplatelet agents are now subdivided and specialized by disease, and many guidelines have been published.

Aging could become the single most important risk factor for arteriosclerosis, owing to the accumulation of genetic mutations. ${ }^{8,9}$ Consequently, elderly people have
Correspondence: Masahisa Arahata Department of Hematology, Graduate School of Medicine of Kanazawa University, I3-I Takaramachi Kanazawa, Ishikawa 920-864I, Japan

Tel +8I 762652274

Fax +8I 762344252

Email m.arahata@staff.kanazawa-u.ac.jp (c) 1 (7) 2018 Arahata and Asakura. This work is published and licensed by Dove Medical Press Limited. The full terms of this license are available at https://www.dovepress.com/terms.php hereby accept the Terms. Non-commercial uses of the work are permitted without any further permission from Dove Medical Press Limited, provided the work is properly attributed. For permission for commercial use of this work, please see paragraphs 4.2 and 5 of our Terms (https://www.dovepress.com/terms.php). 
an increased incidence of thrombosis, even if they have no other risk factors for arteriosclerosis. Separately, many clinical studies of antithrombotic therapy have demonstrated that elderly people are at higher risk of bleeding than younger individuals. ${ }^{10,11}$ Thus, elderly people have increased risks for both thrombosis and bleeding. This phenomenon precludes the use of clinical research data obtained with younger generations for the treatment of elderly patients, making it difficult to choose appropriate antithrombotic strategies for elderly patients. Furthermore, elderly patients frequently have multiple comorbid conditions. As a result, even when physicians newly identify a symptom or a high-risk factor for thrombosis in these patients, they are often unable to start antithrombotic therapy immediately. In such cases, physicians find it challenging to integrate the principles of evidence-based practice into the therapy and must determine the best treatment option for each patient. Figure 1 summarizes the problems identified so far regarding antithrombotic treatment in elderly patients. They can be classified into three categories: 1) polypharmacy; 2) comorbidity; and 3) medication adherence. ${ }^{12-14}$ It is a daunting task to establish a clear and universal treatment plan for all patients. Thus, physicians evaluate these problems and ultimately choose a therapeutic strategy for each patient based on the balance between thrombotic and bleeding risks. They also need to implement an interdisciplinary approach aimed at maintaining the overall health of the patient rather than an intervention tailored for one particular organ or disease. Thus, to help facilitate their decision-making processes, recent findings related to the evidence regarding concomitant medications, secondary benefits of antithrombotic therapy for patients with comorbidities, and evidence regarding medication adherence are reviewed. In this article, people aged 65 years and older are defined as elderly.

\section{Evidence in combined drug use with an antithrombotic agent}

Elderly people frequently suffer from various co-existing medical problems ${ }^{15,16}$ forcing them to take multiple drugs concomitantly. The incidence of adverse drug reactions is significantly higher in patients taking six or more drugs. ${ }^{17}$

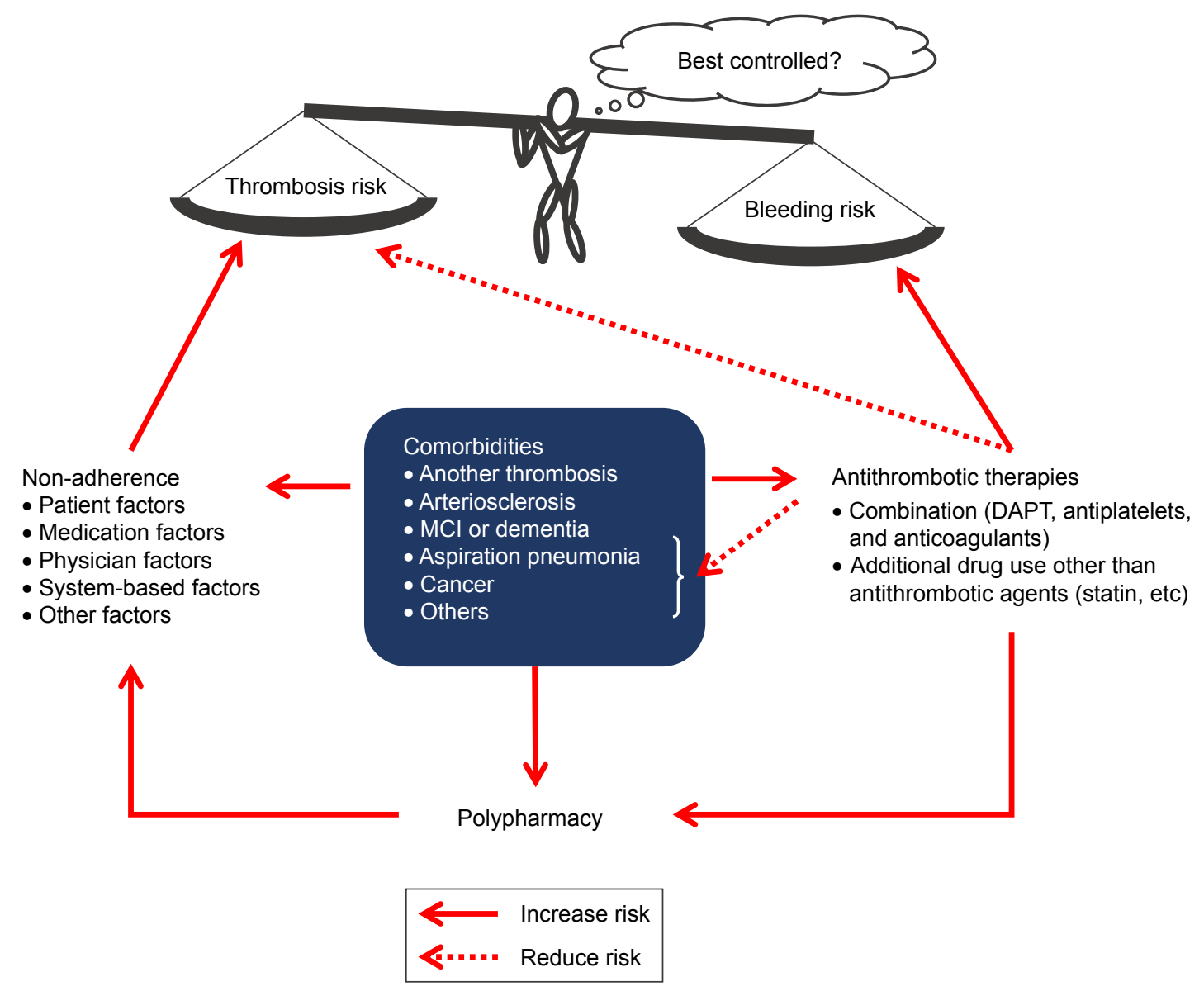

Figure I Problems in antithrombotic therapy for elderly patients with comorbidities.

Notes: The five factors of non-adherence were originally proposed by Yap et al in a systematic review. ${ }^{88}$ Comorbidities can cause several factors that are associated with thrombosis or bleeding risks in patients treated with antithrombotic agents. Therefore, especially in elderly patients, we do our best to provide appropriate prescriptions, considering their comorbidities and avoidance of polypharmacy, as well as interventions to improve adherence.

Abbreviations: DAPT, dual antiplatelet therapy; $\mathrm{MCl}$, mild cognitive impairment. 
Furthermore, the concurrent use of multiple antithrombotic drugs itself increases the risk of bleeding in patients aged 75 years and older. ${ }^{18}$ Because of these adverse events caused by multidrug regimens, and also based on the medical economic considerations, the Japan Geriatrics Society has issued a set of guidelines aimed at minimizing the negative consequences of polypharmacy. ${ }^{19}$ Simple discontinuation of antithrombotic drugs would certainly increase the risk of thrombosis. Thus, in selecting the right drug(s) for each patient, physicians must implement an evidence-based approach, whenever possible.

\section{Concurrent use of multiple antithrombotic drugs}

In the "Guidelines for Medical Treatment and Its Safety in the Elderly 2015," the Japan Geriatrics Society recommends that the concurrent use of multiple antithrombotic drugs be limited to the short-term period of 12 months. ${ }^{19}$ The efficacy of multidrug antithrombotic therapy has only been clearly established for certain select diseases as described below. Thus, the therapy is unsubstantiated and may even be harmful for elderly patients with other types of diseases. Low-dose aspirin is sometimes prescribed for elderly patients who have no clear history of thrombosis. However, the efficacy of this therapy as a primary prevention strategy has not been confirmed in elderly people even for high-risk patients. ${ }^{20}$ This is mainly because, although antithrombotic agents prevent thrombosis, they significantly increase the incidence of intracranial hemorrhage. In fact, antithrombotic therapy has been shown to be the most significant risk factor for this type of bleeding event. ${ }^{21}$

The onset of a new myocardial or cerebral infarction can often be found in elderly patients who have previously been treated with single-drug antithrombotic therapy as secondary prevention. In these cases, physicians are sometimes hesitant to continue using the same therapy without any additional antithrombotic drug against relapses. Recently, researchers have been gathering new information about the concurrent use of multiple antithrombotic drugs. However, physicians must note that much of the information lacks a sufficient amount of data collected from elderly patients. Table 1 shows major antithrombotic combination therapies reported thus far, with a focus on dual antiplatelet therapy (DAPT). ${ }^{22-38}$ DAPT is recommended for the treatment of coronary artery diseases (CADs) in the early stages after stenting. As described below, the optimum duration of the therapy has yet to be determined. In PADs, on the other hand, the efficacy of DAPT has not been established due to the paucity of clinical evidence. ${ }^{39}$ For patients with noncardiogenic

Table I The clinical studies of DAPT

\begin{tabular}{|c|c|c|c|c|c|}
\hline Disease & Subjects & Assignment $(\mathrm{N}, \text { age })^{\mathrm{a}}$ & $\begin{array}{l}\text { Primary endpoint and } \\
\text { follow-up duration }\end{array}$ & Results and/or conclusions & Reference \\
\hline$\overline{C A D}$ & $\begin{array}{l}\text { Patients who } \\
\text { underwent coronary } \\
\text { stenting (BMS) }\end{array}$ & $\begin{array}{l}\text { Aspirin alone }(\mathrm{N}=557, \\
6 \mathrm{I} \text { years }) \text { vs aspirin }+\mathrm{Wa} \\
(\mathrm{N}=550,62 \text { years }) \text { vs } \\
\text { aspirin }+ \text { ticlopidine } \\
(\mathrm{N}=546,61 \text { years })\end{array}$ & $\begin{array}{l}\text { All clinical events } \\
\text { reflecting stent } \\
\text { thrombosis (death, } \\
\text { revascularization of } \\
\text { the target lesion, } \\
\text { angiographically evident } \\
\text { thrombosis, or MI) } \\
\text { within } 30 \text { days }\end{array}$ & $\begin{array}{l}\text { As compared with aspirin } \\
\text { alone and a combination of } \\
\text { aspirin and Wa, treatment } \\
\text { with aspirin and ticlopidine } \\
\text { resulted in a lower rate of stent } \\
\text { thrombosis ( } 3.6 \% \text { vs } 2.7 \% \text { vs } \\
0.5 \% \text {, respectively, } P=0.00 \mathrm{I}) \\
\text { although there were more } \\
\text { hemorrhagic complications } \\
\text { than with aspirin alone }(I .8 \% \\
\text { vs } 6.2 \% \text { vs } 5.5 \% \text {, respectively, } \\
P<0.00 \mathrm{I})\end{array}$ & 22 \\
\hline CAD & $\begin{array}{l}\text { Patients who } \\
\text { underwent coronary } \\
\text { stenting (EES) }\end{array}$ & $\begin{array}{l}\text { Discontinuation of } \\
\text { DAPT within } 4 \text { months } \\
\text { ( } N=I, 525,70.0 \text { years), } \\
\text { vs continuation of } \\
\text { DAPT for over I year } \\
\text { ( } N=1,559,68.9 \text { years) }\end{array}$ & $\begin{array}{l}\text { A composite of } \\
\text { cardiovascular death, } \\
\text { MI, stroke, definite } \\
\text { stent thrombosis, and } \\
\text { thrombolysis in MI } \\
\text { major/minor bleeding at } \\
\text { I year after PCl }\end{array}$ & $\begin{array}{l}\text { Cumulative incidence of the } \\
\text { primary endpoint tended to be } \\
\text { lower in the discontinuation } \\
\text { group than in the continuation } \\
\text { group }(2.8 \% \text { vs } 4.0 \%, P=0.06) \\
\text { and adjusted HR was } 0.64 \\
(95 \% \mathrm{Cl}, 0.42 \text { to } 0.95, P=0.03) \text {. } \\
\text { Stopping DAPT at } 3 \text { months in } \\
\text { selected patients after cobalt- } \\
\text { chromium EES implantation was } \\
\text { at least as safe as the prolonged } \\
\text { DAPT regimen }\end{array}$ & 23 \\
\hline
\end{tabular}


Table I (Continued)

\begin{tabular}{|c|c|c|c|c|c|}
\hline Disease & Subjects & Assignment $(\mathrm{N}, \text { age })^{\mathrm{a}}$ & $\begin{array}{l}\text { Primary endpoint and } \\
\text { follow-up duration }\end{array}$ & Results and/or conclusions & Reference \\
\hline CAD & $\begin{array}{l}\text { Patients who } \\
\text { underwent coronary } \\
\text { stenting (DES) and } \\
\text { treated with DAPT } \\
\text { for } 12 \text { months }\end{array}$ & $\begin{array}{l}\text { Aspirin }+ \text { thienopyridine } \\
(\mathrm{N}=5,020,6 \mathrm{I} .8 \text { years }) \\
\text { vs aspirin + placebo } \\
(\mathrm{N}=4,94 \mathrm{I}, 6 \mathrm{I} .6 \text { years })\end{array}$ & $\begin{array}{l}\text { Stent thrombosis } \\
\text { and major adverse } \\
\text { cardiovascular and } \\
\text { cerebrovascular events } \\
\text { (the composite of death, } \\
\text { Ml, or stroke) during } \\
\text { the period from } 12 \text { to } \\
30 \text { months after PCl }\end{array}$ & $\begin{array}{l}\text { As compared with aspirin } \\
\text { alone, DAPT significantly } \\
\text { reduced the risks of stent } \\
\text { thrombosis }(\mathrm{HR}, 0.29 ; 95 \% \mathrm{Cl} \text {, } \\
0.17 \text { to } 0.48 ; \mathrm{P}<0.00 \mathrm{I}) \text { and } \\
\text { major adverse cardiovascular } \\
\text { and cerebrovascular events } \\
(\mathrm{HR}, 0.7 \mathrm{I} ; 95 \% \mathrm{Cl}, 0.59 \text { to } \\
0.85 ; P<0.00 \mathrm{I}) \text { but was } \\
\text { associated with an increased } \\
\text { risk of bleeding ( } 2.5 \% \text { vs } \mathrm{I} .6 \% \text {, } \\
P=0.00 \mathrm{I})\end{array}$ & 24 \\
\hline CAD & $\begin{array}{l}\text { Patients who } \\
\text { underwent coronary } \\
\text { stenting }>6 \text { months } \\
\text { previously }\end{array}$ & $\begin{array}{l}\text { Aspirin + cilostazol } \\
(\mathrm{N}=254,68 \text { years }) \text { vs } \\
\text { aspirin alone }(\mathrm{N}=260 \text {, } \\
69 \text { years })\end{array}$ & $\begin{array}{l}\text { A composite of all-cause } \\
\text { death, MI, stroke, } \\
\text { or cardiovascular } \\
\text { or cerebrovascular } \\
\text { revascularization } \\
\text { at } 2 \text { years after } \\
\text { randomization }\end{array}$ & $\begin{array}{l}\text { The addition of cilostazol } \\
\text { to aspirin therapy was } \\
\text { associated with lower } \\
\text { rates of cardiovascular and } \\
\text { cerebrovascular events at } \\
2 \text { years compared with aspirin } \\
\text { monotherapy ( } 13.9 \% \text { vs } 22.1 \% \text {; } \\
\text { HR, } 0.6 \mathrm{I} ; 95 \% \mathrm{Cl}, 0.40 \text { to } 0.93 \text {; } \\
P=0.02 \mathrm{I}) \text {. The rate of major } \\
\text { or minor bleeding was not } \\
\text { significantly different between } \\
\text { the two groups }\end{array}$ & 25 \\
\hline CAD & $\begin{array}{l}\text { Patients receiving } \\
\text { oral anticoagulants } \\
\text { and undergoing } \mathrm{PCl} \\
(\mathrm{DES})\end{array}$ & $\begin{array}{l}\text { Wa + clopidogrel } \\
(\mathrm{N}=279,70.3 \text { years, } \\
\text { double therapy) vs } \mathrm{Wa}+ \\
\text { clopidogrel + aspirin } \\
(\mathrm{N}=284,69.5 \text { years, } \\
\text { triple therapy) }\end{array}$ & $\begin{array}{l}\text { Any bleeding episode } \\
\text { within I year of } \mathrm{PCl} \text {, } \\
\text { assessed by intention } \\
\text { to treat }\end{array}$ & $\begin{array}{l}\text { Use of clopidogrel without } \\
\text { aspirin (double therapy) } \\
\text { was associated with a } \\
\text { significant reduction in } \\
\text { bleeding complications } \\
\text { (HR, } 0.36 ; 95 \% \mathrm{Cl}, 0.26 \\
\text { to } 0.50 ; P<0.000 \mathrm{I} \text { ) and } \\
\text { no increase in the rate of } \\
\text { thrombotic events }\end{array}$ & 26 \\
\hline CAD & $\begin{array}{l}\text { Patients with atrial } \\
\text { fibrillation who had } \\
\text { undergone } \mathrm{PCl}\end{array}$ & $\begin{array}{l}\text { Dabigatran } 220 \mathrm{mg} / \\
\text { day + clopidogrel or } \\
\text { ticagrelor }(\mathrm{N}=98 \mathrm{I}, \\
71.5 \text { years, } 110 \mathrm{mg} \text { dual } \\
\text { therapy) vs dabigatran } \\
300 \mathrm{mg} / \text { day + } \\
\text { clopidogrel or ticagrelor } \\
(\mathrm{N}=763,68.6 \text { years, } \\
150 \mathrm{mg} \text { dual therapy) } \\
\text { vs } \mathrm{Wa}+\text { aspirin }+ \\
\text { clopidogrel or ticagrelor } \\
(\mathrm{N}=98 \mathrm{I}, 7 \mathrm{I} .7 \text { years, } \\
\text { triple therapy) }\end{array}$ & $\begin{array}{l}\text { A major or clinically } \\
\text { relevant non-major } \\
\text { bleeding event during } \\
\text { follow-up. Mean follow- } \\
\text { up was } 14 \text { months }\end{array}$ & $\begin{array}{l}\text { Bleeding was lower among } \\
\text { those who received dual } \\
\text { therapy than among those } \\
\text { who received triple therapy } \\
\text { ( } 15.4 \% \text { in the I I } 0 \text { mg dual } \\
\text { therapy group as compared } \\
\text { with } 26.9 \% \text { in the triple } \\
\text { therapy group [HR, } 0.52 ; 95 \% \\
\mathrm{Cl}, 0.42 \text { to } 0.63 ; P<0.00 \text { I for } \\
\text { non-inferiority; } P<0.00 \text { I for } \\
\text { superiority], and } 20.2 \% \text { in the } \\
\text { I50 mg dual therapy group as } \\
\text { compared with } 25.7 \% \text { in the } \\
\text { corresponding triple therapy } \\
\text { group, which did not include } \\
\text { elderly patients outside the } \\
\text { United States [HR, } 0.72 ; 95 \% \\
\text { Cl, } 0.58 \text { to } 0.88 ; P<0.00 I \text { for } \\
\text { non-inferiority]). Dual therapy } \\
\text { was non-inferior to triple } \\
\text { therapy with respect to the risk } \\
\text { of thromboembolic events }\end{array}$ & 27 \\
\hline
\end{tabular}


Table I (Continued)

\begin{tabular}{|c|c|c|c|c|c|}
\hline Disease & Subjects & Assignment $(\mathrm{N}, \text { age })^{\mathrm{a}}$ & $\begin{array}{l}\text { Primary endpoint and } \\
\text { follow-up duration }\end{array}$ & Results and/or conclusions & Reference \\
\hline CAD & $\begin{array}{l}\text { Patients undergoing } \\
\text { CABG }\end{array}$ & $\begin{array}{l}\text { Ticagrelor }+ \text { aspirin } \\
(\mathrm{N}=168,63.5 \text { years }) \\
\text { vs ticagrelor alone } \\
(\mathrm{N}=166,63.3 \text { years }) \text { vs } \\
\text { aspirin alone }(\mathrm{N}=166, \\
64.0 \text { years })\end{array}$ & $\begin{array}{l}\text { Primary outcome was } \\
\text { saphenous vein graft } \\
\text { patency I year after } \\
\text { CABG }\end{array}$ & $\begin{array}{l}\text { Saphenous vein graft patency } \\
\text { rates I year post-CABG } \\
\text { were } 88.7 \% \text { with ticagrelor }+ \\
\text { aspirin; } 82.8 \% \text { with ticagrelor } \\
\text { alone; and } 76.5 \% \text { with aspirin } \\
\text { alone. The difference between } \\
\text { ticagrelor + aspirin vs aspirin } \\
\text { alone was statistically significant } \\
(12.2 \% ; 95 \% \mathrm{Cl}, 5.2 \% \text { to } \\
19.2 \% ; P<0.00 \mathrm{I}) \text {. Further } \\
\text { research with more patients is } \\
\text { needed to assess comparative } \\
\text { bleeding risks }\end{array}$ & 28 \\
\hline PAD & $\begin{array}{l}\text { Patients with } \\
\text { a history of } \\
\text { intermittent } \\
\text { claudication } \\
\text { secondary to PAD }\end{array}$ & $\begin{array}{l}\text { Aspirin + cilostazol } \\
(\mathrm{N}=717,66.5 \text { years }) \\
\text { vs aspirin + placebo } \\
(\mathrm{N}=718,65.9 \text { years })\end{array}$ & $\begin{array}{l}\text { The safety of cilostazol, } \\
\text { defined as all-cause } \\
\text { mortality within } \\
36 \text { months after } \\
\text { randomization }\end{array}$ & $\begin{array}{l}\text { In the full ITT population at } \\
36 \text { months, there were I0I } \\
\text { deaths, } 49 \text { on cilostazol and } 52 \\
\text { on placebo (HR, } 0.94 ; 95 \% \mathrm{Cl} \text {, } \\
0.64 \text { to I.39; } P=0.77) \text {. Serious } \\
\text { bleeding events appeared not to } \\
\text { be increased by cilostazol }\end{array}$ & 29 \\
\hline PAD & $\begin{array}{l}\text { The patients with } \\
\text { symptomatic or } \\
\text { asymptomatic } \\
\text { PAD from the } \\
\text { CHARISMA trial }\end{array}$ & $\begin{array}{l}\text { Aspirin + clopidogrel } \\
(\mathrm{N}=1,545,66 \text { years }) \\
\text { vs aspirin + placebo } \\
(\mathrm{N}=1,55 \mathrm{I}, 66 \text { years })\end{array}$ & $\begin{array}{l}\text { The first occurrence } \\
\text { of MI, stroke, or death } \\
\text { from cardiovascular } \\
\text { causes (including } \\
\text { hemorrhage). Patients } \\
\text { were followed up for a } \\
\text { median of } 28 \text { months }\end{array}$ & $\begin{array}{l}\text { Among the patients with PAD, } \\
\text { the primary endpoint occurred } \\
\text { in } 7.6 \% \text { in the clopidogrel plus } \\
\text { aspirin group and } 8.9 \% \text { in the } \\
\text { placebo plus aspirin group } \\
\text { (HR, } 0.85 ; 95 \% \mathrm{Cl}, 0.66 \text { to } 1.08 \text {; } \\
P=0.18 \text { ). DAPT provided some } \\
\text { benefit over aspirin alone in } \\
\text { PAD patients for the rate of } \mathrm{MI} \\
\text { and the rate of hospitalization } \\
\text { for ischemic events, at the cost } \\
\text { of an increase in minor bleeding }\end{array}$ & 30 \\
\hline PAD & $\begin{array}{l}\text { Patients undergoing } \\
\text { unilateral, below- } \\
\text { knee bypass graft } \\
\text { for atherosclerotic } \\
\text { PAD }\end{array}$ & $\begin{array}{l}\text { Aspirin + clopidogrel } \\
(\mathrm{N}=425,66.5 \text { years }) \\
\text { vs aspirin + placebo } \\
(\mathrm{N}=426,65.6 \text { years })\end{array}$ & $\begin{array}{l}\text { A composite of index } \\
\text { graft occlusion or } \\
\text { revascularization, above- } \\
\text { ankle amputation of the } \\
\text { affected limb, or death at } \\
6 \text { to } 24 \text { months }\end{array}$ & $\begin{array}{l}\text { The combination of clopidogrel } \\
\text { plus aspirin did not improve } \\
\text { limb or systemic outcomes in } \\
\text { the overall population of PAD } \\
\text { patients requiring below-knee } \\
\text { bypass grafting (HR, } 0.98 ; 95 \% \\
\mathrm{Cl}, 0.78 \text { to } 1.23 \text { ). Subgroup } \\
\text { analysis suggests that } \\
\text { clopidogrel plus aspirin confers } \\
\text { benefit in patients receiving } \\
\text { prosthetic grafts without } \\
\text { significantly increasing major } \\
\text { bleeding risk }\end{array}$ & 31 \\
\hline PAD & $\begin{array}{l}\text { Patients with PAD } \\
\text { and acute coronary } \\
\text { syndromes }\end{array}$ & $\begin{array}{l}\text { Aspirin }+ \text { ticagrelor vs } \\
\text { aspirin }+ \text { clopidogrel } \\
\text { (total } N=I, 144 \text { ) }\end{array}$ & $\begin{array}{l}\text { Cardiovascular death, } \\
\text { MI, or stroke for I year }\end{array}$ & $\begin{array}{l}\text { The reduction of cardiovascular } \\
\text { death, MI, or stroke with } \\
\text { ticagrelor compared with } \\
\text { clopidogrel in PAD patients was } \\
\text { consistent with the overall trial } \\
\text { result although it did not reach } \\
\text { statistical significance (HR, } 0.85 \text {; } \\
95 \% \mathrm{Cl}, 0.64 \text { to I.I I; } P=0.99 \text { ). } \\
\text { Overall major bleeding was } \\
\text { similar between the therapies }\end{array}$ & 32 \\
\hline
\end{tabular}


Table I (Continued)

\begin{tabular}{|c|c|c|c|c|c|}
\hline Disease & Subjects & Assignment $(\mathrm{N}, \text { age })^{\mathrm{a}}$ & $\begin{array}{l}\text { Primary endpoint and } \\
\text { follow-up duration }\end{array}$ & Results and/or conclusions & Reference \\
\hline PAD & $\begin{array}{l}\text { Patients undergoing } \\
\text { an initial elective } \\
\text { lower extremity } \\
\text { revascularization } \\
\text { (bypass or } \\
\text { endovascular) }\end{array}$ & $\begin{array}{l}\text { Bypass: aspirin } \\
(\mathrm{N}=9,967,67.3 \text { years }) \text {, } \\
\text { aspirin }+ \text { thienopyridine } \\
(\mathrm{N}=6,018,66.6 \text { years }) \\
\text { Endovascular: aspirin } \\
(\mathrm{N}=12,559,69.1 \\
\text { years), aspirin }+ \\
\text { thienopyridine } \\
(\mathrm{N}=28,497,67.6 \text { years })\end{array}$ & $\begin{array}{l}\text { Retrospective analysis } \\
\text { compared late survival at } \\
\text { I year and } 5 \text { years after } \\
\text { revascularizations }\end{array}$ & $\begin{array}{l}\text { DAPT was associated with } \\
\text { prolonged survival compared } \\
\text { with aspirin alone at I year after } \\
\text { bypass }(93 \% \text { vs } 92 \%, P=0.00 \text { I) } \\
\text { and endovascular interventions } \\
(93 \% \text { vs } 92 \%, P=0.005) \text { and } \\
\text { that was sustained through } \\
5 \text { years of follow-up (bypass, } \\
80 \% \text { vs } 78 \%[P=0.004] \text {; } \\
\text { endovascular, } 76 \% \text { vs } 73 \% \\
[P=0.002]) \text {, but not for those } \\
\text { with claudication }\end{array}$ & 33 \\
\hline Stroke and TIA & $\begin{array}{l}\text { Patients within } \\
24 \text { hours after the } \\
\text { onset of minor } \\
\text { ischemic stroke or } \\
\text { high-risk TIA }\end{array}$ & $\begin{array}{l}\text { Aspirin }+ \text { clopidogrel } \\
(\mathrm{N}=2,584,63 \text { years }) \\
\text { vs aspirin alone } \\
(\mathrm{N}=2,586,62 \text { years })\end{array}$ & $\begin{array}{l}\text { Stroke (ischemic or } \\
\text { hemorrhagic) during } \\
90 \text { days of follow-up }\end{array}$ & $\begin{array}{l}\text { The combination of clopidogrel } \\
\text { and aspirin is superior to } \\
\text { aspirin alone for reducing } \\
\text { the risk of stroke in the first } \\
90 \text { days }(\mathrm{HR}, 0.68 ; 95 \% \mathrm{Cl} \text {, } \\
0.57 \text { to } 0.8 \mathrm{I} ; \mathrm{P}<0.00 \mathrm{I}) \text { and } \\
\text { does not increase the risk of } \\
\text { hemorrhage }\end{array}$ & 34 \\
\hline Stroke and TIA & $\begin{array}{l}\text { Patients with recent } \\
\text { ischemic stroke or } \\
\text { TIA and at least one } \\
\text { additional vascular } \\
\text { risk factor }\end{array}$ & $\begin{array}{l}\text { Aspirin + clopidogrel } \\
(\mathrm{N}=3,797,66.5 \text { years }) \\
\text { vs placebo + clopidogrel } \\
(\mathrm{N}=3,802,66.1 \text { years })\end{array}$ & $\begin{array}{l}\text { A composite of } \\
\text { ischemic stroke, MI, } \\
\text { vascular death, or } \\
\text { rehospitalization for } \\
\text { acute ischemia during } \\
\text { I8 months }\end{array}$ & $\begin{array}{l}\text { Adding aspirin to clopidogrel } \\
\text { in high-risk patients with } \\
\text { recent ischemic stroke or } \\
\text { TIA is associated with a } \\
\text { non-significant difference } \\
\text { in reducing major vascular } \\
\text { events (relative risk reduction, } \\
6.4 \% \text {; } 95 \% \mathrm{Cl} \text {, to } 4.6 \text { to } 16.3 \text {; } \\
\text { absolute risk reduction, } 1 \% \\
\text { [ }-0.6 \text { to } 2.7] \text { ). The risk of life } \\
\text { threatening or major bleeding } \\
\text { is increased by the addition } \\
\text { of aspirin }\end{array}$ & 35 \\
\hline Stroke and TIA & $\begin{array}{l}\text { Patients with minor } \\
\text { ischemic stroke or } \\
\text { high-risk TIA }\end{array}$ & $\begin{array}{l}\text { Aspirin + clopidogrel } \\
(\mathrm{N}=2,432,65.0 \text { years }) \\
\text { vs aspirin + placebo } \\
(\mathrm{N}=2,449,65.0 \text { years })\end{array}$ & $\begin{array}{l}\text { The risk of a composite } \\
\text { of ischemic stroke, MI, } \\
\text { or death from ischemic } \\
\text { vascular causes (major } \\
\text { ischemic events). } \\
\text { Patients were to be } \\
\text { followed up for } 90 \text { days } \\
\text { after randomization }\end{array}$ & $\begin{array}{l}\text { Patients received a combination } \\
\text { of clopidogrel and aspirin had } \\
\text { a lower risk of major ischemic } \\
\text { events ( } 5.0 \% \text { in DAPT vs } \\
6.5 \% \text { in aspirin plus placebo } \\
{[\mathrm{HR}, 0.75 ; 95 \% \mathrm{Cl}, 0.59 \text { to }} \\
0.95 ; P=0.02] \text { but a higher } \\
\text { risk of major hemorrhage } 0.9 \% \\
\text { in DAPT vs } 0.4 \% \text { in aspirin } \\
\text { plus placebo [HR, } 2.32 ; 95 \% \\
\mathrm{Cl}, \mathrm{I} .10 \text { to } 4.87 ; \mathrm{P}=0.02] \text { ) at } \\
90 \text { days than patients received } \\
\text { aspirin alone }\end{array}$ & 36 \\
\hline $\begin{array}{l}\text { A composite of } \\
\text { cardiovascular } \\
\text { diseases }\end{array}$ & $\begin{array}{l}\text { Patients with either } \\
\text { clinically evident } \\
\text { cardiovascular } \\
\text { disease or multiple } \\
\text { risk factors }\end{array}$ & $\begin{array}{l}\text { Aspirin + clopidogrel } \\
(\mathrm{N}=7,802,64.0 \text { years }) \\
\text { vs aspirin + placebo } \\
(\mathrm{N}=7,80 \mathrm{I}, 64.0 \text { years })\end{array}$ & $\begin{array}{l}\text { A composite of MI, } \\
\text { stroke, or death from } \\
\text { cardiovascular causes }\end{array}$ & $\begin{array}{l}\text { Clopidogrel plus aspirin was not } \\
\text { significantly more effective than } \\
\text { aspirin alone in reducing the } \\
\text { rate of } \mathrm{MI} \text {, stroke, or death from } \\
\text { cardiovascular causes (relative } \\
\text { risk, } 0.93 ; 95 \% \mathrm{Cl}, 0.83 \text { to I.05; } \\
P=0.22 \text { ) }\end{array}$ & 37 \\
\hline
\end{tabular}


Table I (Continued)

\begin{tabular}{|c|c|c|c|c|c|}
\hline Disease & Subjects & Assignment $(\mathbf{N}, \text { age })^{a}$ & $\begin{array}{l}\text { Primary endpoint and } \\
\text { follow-up duration }\end{array}$ & Results and/or conclusions & Reference \\
\hline $\begin{array}{l}\text { A composite of } \\
\text { cardiovascular } \\
\text { diseases }\end{array}$ & $\begin{array}{l}\text { Patients who } \\
\text { were taking oral } \\
\text { antithrombotic } \\
\text { agents for stroke } \\
\text { and cardiovascular } \\
\text { diseases }\end{array}$ & $\begin{array}{l}\text { Single antiplatelet } \\
\text { agent }(\mathrm{N}=\mathrm{I}, 89 \mathrm{I}, \\
69 \text { years) vs DAPT } \\
(\mathrm{N}=349,69 \text { years }) \\
\text { vs } \mathrm{Wa}(\mathrm{N}=1,298, \\
68 \text { years }) \text { vs } \mathrm{Wa}+ \\
\text { antiplatelet agent } \\
(\mathrm{N}=47 \mathrm{I}, 70 \text { years })\end{array}$ & $\begin{array}{l}\text { Life threatening or major } \\
\text { bleeding. Duration of the } \\
\text { median follow-up was } \\
19 \text { months }\end{array}$ & $\begin{array}{l}\text { The annual incidence of the } \\
\text { primary endpoint was } 1.21 \% \\
\text { in the single antiplatelet agent } \\
\text { group, } 2.00 \% \text { in the dual } \\
\text { antiplatelet agent group, } 2.06 \% \\
\text { in the Wa group, and } 3.56 \% \\
\text { in the Wa plus antiplatelet } \\
\text { agent group ( } P<0.00 \mathrm{I} \text { ). Dual } \\
\text { antithrombotic therapy was } \\
\text { independently related to an } \\
\text { increased risk of bleeding } \\
\text { events }\end{array}$ & 38 \\
\hline
\end{tabular}

Notes: The important large-scale clinical studies were extracted in the table, including non-RCTs and retrospective studies. ${ }^{a}$ Age is expressed as the mean or median age of each allocated group as described in the referenced articles.

Abbreviations: BMS, bare metal stent; CABG, coronary artery bypass grafting; CAD, coronary artery disease; DAPT, dual antiplatelet therapy; DES, drug-eluting stent; EES, everolimus-eluting stent; ITT, intention to treat; MI, myocardial infarction; PAD, peripheral arterial disease; PCI, percutaneous coronary intervention; RCT, randomized controlled trial; TIA, transient ischemic attack; Wa, warfarin.

cerebral infarction, DAPT is proven to be effective in preventing relapse during the early stages of the disease, but the available information is still limited (Table 1). In contrast, atrial fibrillation patients requiring anticoagulation therapy with concurrent CAD appear to benefit very little from triple therapy where an anticoagulant is combined with post-stenting DAPT (Table 1) ${ }^{26,27}$ Similarly, the augmentation of an anticoagulant with antiplatelet therapy has no added positive effect in atrial fibrillation patients with stable cardiovascular disease (or its risk) that does not require percutaneous coronary intervention (PCI).$^{40}$ However, the concomitant administration of these antithrombotic (anticoagulant + antiplatelet) therapies undoubtedly increases the risk of bleeding. ${ }^{41}$ The "COMPASS study" evaluated the effect of the concurrent use of rivaroxaban and aspirin in patients with stable cardiovascular disease. ${ }^{42}$ The results indicated that, compared with aspirin alone, the combination therapy significantly reduced the incidence of adverse cardiovascular events. However, bleeding events occurred in significantly more patients treated with the combination therapy. When the composite endpoint (net clinical benefit outcome of death, cerebral infarction, myocardial infarction, fatal bleeding, and symptomatic bleeding) was analyzed, the total incidence of events was significantly lower in the combination therapy group than in the aspirin alone group (HR, $0.80 ; 95 \% \mathrm{CI}$, $0.70-0.91)$. However, a subgroup analysis showed that the rates of thrombotic and bleeding events increased with age. Thus, in patients aged 75 years and older, there was no significant difference in the thrombotic endpoint (cardiovascular death, stroke, and myocardial infarction) between the two treatment groups (HR, $0.89 ; 95 \% \mathrm{CI}, 0.69-1.14){ }^{42}$ Collectively, the results of these clinical studies indicate the effectiveness of concomitant antithrombotic therapies only in the early (or acute) stage of thrombosis based on arteriosclerotic lesions. However, they also suggest that although the risk of thrombosis decreases, the increased risk of bleeding resulting from the antithrombotic therapies becomes a significant issue as the disease progresses to the chronic stage. In elderly patients, it is especially difficult to obtain therapeutic benefit that outweighs the risk of bleeding from the concurrent use of antithrombotic drugs. It should be noted that some studies listed in Table 1 were reported in the era before the availability of direct oral anticoagulants (DOACs) and newer antiplatelet agents such as ticagrelor. Therefore, some concomitant antithrombotic therapies might be no longer selected in actual clinical practice. These therapeutic methods remain to be improved in terms of their regimens, duration of medications, and decisions regarding indications for patients. In recent years, evidence-based guidelines, including a single drug of antithrombotic therapy, have been developed for each specialized medical field, and physicians should consult them when treating patients.

As noted above, some clinical trials listed in Table 1 were reported before the era of DOACs and newer antiplatelet agents such as ticagrelor. Therefore, more clinical trials using these new drugs are required to prove the usefulness of concurrent use of multiple antithrombotic drugs. Furthermore, elderly patients with diseases other than those described here should not receive concomitant antithrombotic therapies, because there is no clear evidence for their efficacy in them. 
However, as explained in the Statin-based combination therapy section, combination therapies involving statins could balance the risks of thrombosis and bleeding to some degree in patients with severe arteriosclerosis.

\section{Statin-based combination therapy}

Cohort studies have demonstrated that, in elderly patients, high levels of serum cholesterol are not associated with an increased risk of thrombotic events or mortality. ${ }^{43,44}$ Thus, statin drugs for hyperlipidemia are often discontinued in elderly patients. As for statins used as secondary prevention after cerebral infarction, Vergouwen et $\mathrm{al}^{45}$ previously demonstrated that these drugs increase the risk of cerebral hemorrhage (pooled relative risk, 1.73; 95\% CI, 1.19-2.50) although they also reduce the incidence of recurrent cerebral infarction (pooled relative risk, 0.80; 95\% CI, 0.70-0.92). They concluded that the thrombotic effect was partly negated by an increased risk of hemorrhagic stroke. ${ }^{45}$ Recently, several reports were published regarding the correlation between statin use and the risks of thrombotic and bleeding events. By using clinical data available from a university hospital in South Korea, Shin et al performed a retrospective analysis of 1,686 patients who had been concomitantly administered warfarin and a statin. ${ }^{46}$ The results indicated that the risk of bleeding was significantly and specifically higher in patients treated with a strong statin (HR, 5.394; 95\% CI 1.168-24.916). The authors suggest that an excessive reduction of low-density lipoprotein (LDL)-cholesterol levels may weaken cellular membranes, resulting in a higher incidence of bleeding. ${ }^{46}$ The increased incidence of bleeding caused by statins could also be explained by the drugs' effects on fibrinolysis and/or anticoagulation. ${ }^{45}$ Moreover, the increase may be related to microhemorrhage that is frequently found in patients with cerebral infarction. ${ }^{45}$ These observations appear to indicate that, when possible, the use of statins should be avoided in elderly patients. However, the discontinuation of statin therapy is reportedly associated with a significantly higher incidence of thrombosis in patients receiving antithrombotic therapy during the early stages after cerebral infarction (adjusted HR, 1.42; 95\% CI, 1.28-1.57) ${ }^{47}$ Furthermore, early statin use after cerebral infarction is shown to significantly improve physical functions 3 months after disease onset (pooled odds ratio, $1.41 ; 95 \%$ CI, 1.29-1.56). ${ }^{48}$ Thus, a considerable number of clinical cases indicate the effectiveness of statins. These studies did not exclusively recruit elderly patients as subjects. However, in all studies, the subjects were on average in their mid-60s. Thus, the results of the studies can provide valuable information about elderly patients.
The results described above can be summarized as follows. When used as primary prevention for thrombosis (or as arteriosclerosis prevention), statin therapy has only limited efficacy in elderly patients. In contrast, statins are potentially necessary for certain patients who already have a high thrombotic risk (severe arteriosclerosis) that could lead to cerebral infarction. This is a clinically relevant research subject that requires further investigation with randomized controlled trials (RCTs). However, when we are unable to easily determine which treatment option is best for our current patients, we adhere to the following principles: 1) we assume that the thrombotic risk is higher than the bleeding risk in patients with severe arteriosclerosis (including those receiving secondary prevention therapy), and for these patients, we consider combining a statin with antithrombotic therapy; and 2) we assume that statin treatment has only limited efficacy in certain patients (such as atrial fibrillation patients with mild-to-moderate arteriosclerosis) receiving anticoagulation therapy, even if they have high levels of total cholesterol (Figure 2). In addition, when patients concomitantly develop thrombosis caused by arteriosclerosis despite already receiving antithrombotic therapy (tertiary prevention setting), physicians may combine a statin, rather than DAPT, with the ongoing therapy as a safety precaution (Figure 2). In any of these cases, currently, there is no substantial reason for using strong statins in elderly patients. Recently, pravasta$\operatorname{tin}(40 \mathrm{mg} /$ day) was found to have no effect on the prevention of cardiovascular events in elderly patients with moderate hyperlipidemia (mean LDL-cholesterol, $148 \mathrm{mg} / \mathrm{dL}$ ) and hypertension. ${ }^{49}$ Thus, similar to antiplatelet therapy, statins should be avoided unless compelling evidence exists for their use in a specific patient.

\section{Optimum duration of DAPT}

Currently, physicians often evaluate bleeding risk before determining the necessity for antithrombotic therapy and/or the drugs suitable for such therapy. Many clinical studies have investigated the optimum duration of DAPT after coronary stenting, but they have not yet reached a universal conclusion. Through these studies, however, physicians have begun to realize the importance of individually evaluating patients' thrombotic and bleeding risks ${ }^{50}$ and have recently developed several scoring systems that can predict these risks more efficiently. The DAPT score was reported as a tool to assess if the further continuation of DAPT would be beneficial for patients who had already received this therapy for 1 year after coronary stenting (Table 2). ${ }^{51}$ Separately, the PRECISE-DAPT score was created as a tool for early decision-making (continuation or termination) with respect 


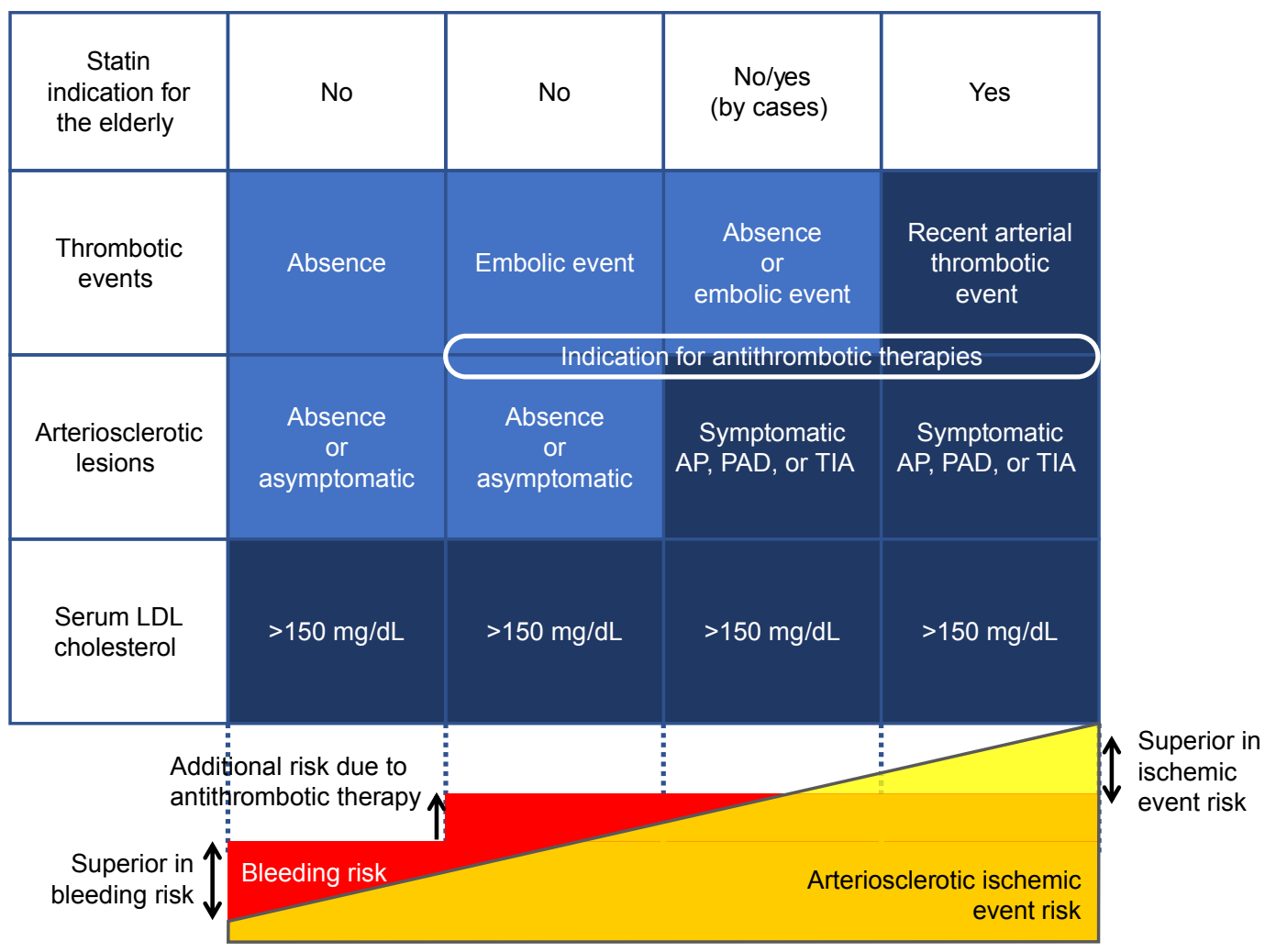

Risk balance after medication of statin

Figure 2 Indications for statins in elderly patients with hyperlipidemia in addition to basic antithrombotic therapy (proposal).

Notes: The bleeding risk can be excessively increased by statins in elderly patients already treated with antithrombotic therapies. Inappropriate statin use will increase their bleeding risk to greater than their ischemic risk. The patients that fit into one of the right three columns have an indication for antithrombotic therapy. Some patients with a past embolic event but with little arteriosclerotic change have an indication for anticoagulant therapy but are not suitable for statins. Embolic events such as cardiogenic cerebral embolism, deep vein thrombosis, and pulmonary embolism can occur independently of underlying arteriosclerotic lesions.

Abbreviations: AP, angina pectoris; PAD, peripheral arterial disease; TIA, transient ischemic attack; LDL, low density lipoprotein.

to the duration of DAPT. ${ }^{52}$ The usefulness of these tools has been gradually recognized based on the results of clinical studies conducted under a variety of research conditions..$^{53-55}$ As the DAPT score decreases, the benefit of prolonged DAPT

\section{Table 2 DAPT score}

\begin{tabular}{ll}
\hline Variable & Points \\
\hline Age (years) & -2 \\
$\geq 75$ & $-\mathrm{I}$ \\
$65-<75$ & 0 \\
$<65$ & $\mathrm{I}$ \\
Cigarette smoking & $\mathrm{I}$ \\
Diabetes mellitus & $\mathrm{I}$ \\
Ml at presentation & $\mathrm{I}$ \\
Prior PCl or prior $\mathrm{MI}$ & $\mathrm{I}$ \\
Paclitaxel-eluting stent & $\mathrm{I}$ \\
Stent diameter $<3 \mathrm{~mm}$ & 2 \\
CHF or LVEF $<30 \%$ & 2 \\
Vein graft stent & 2 \\
\hline
\end{tabular}

Notes: Variables reflect characteristics at the time of the index procedure. Cigarette smoking was defined as smoking within I year prior to the index procedure. The total score can range from -2 to 10 . Discontinuation of DAPT is recommended for patients with a low score on this scoring system.

Abbreviations: CHF, congestive heart failure; DAPT, dual antiplatelet therapy; LVEF, left ventricular ejection fraction; MI, myocardial infarction; $\mathrm{PCl}$, percutaneous coronary intervention. decreases and the risk of bleeding increases. The only factor that reduces DAPT scores is advanced age ( -1 for age $\geq 65$ and $<75$ years and -2 for age $\geq 75$ years). Consequently, the number of patients who should continue the therapy for extended periods of time is lower among elderly patients. In fact, a large-scale retrospective assessment of actual clinical cases demonstrated that most patients with DAPT scores $<2$ were elderly patients and that prolonged DAPT was harmful to them. ${ }^{54}$

\section{Secondary benefits of antithrombotic therapy}

Apart from its main purpose of preventing thrombotic events, antithrombotic therapy has, at times, positive effects on co-existing medical conditions that are frequently found in elderly patients. These secondary benefits may play a vital role not only in the maintenance and improvement of quality of life but also in prolonging life expectancy. Consequently, physicians may decide to use a specific antithrombotic drug with a known secondary benefit for a certain patient. The following are a few examples of these secondary benefits. 


\section{Prevention of aspiration pneumonia by cilostazol}

Aspiration pneumonia is a leading cause of hospitalization and mortality in elderly people, especially in those with oropharyngeal dysphagia. ${ }^{56,57}$ Because of the increasing number of older patients with pneumonia in aging societies, ${ }^{58}$ effective prophylaxis for aspiration pneumonia in needed. In 2001, Yamaya et al ${ }^{59}$ performed an RCT involving patients with cerebral infarction. In this trial, one group (152 patients) received cilostazol (100 $\mathrm{mg} /$ day) and the other (145 patients) received no treatment. They reported that cilostazol administration after cerebral infarction lowered the risk of pneumonia about $40 \% .{ }^{59}$ Following this article, similar observations have occasionally been published. ${ }^{60,61}$ Moreover, the use of cilostazol as a preventive measure for aspiration pneumonia was described in the "Japanese Guidelines for the Management of Stroke 2015" issued by the Japan Stroke Society. ${ }^{62}$ Mechanistically, cilostazol may stimulate blood flow in the basal ganglia region and improve the cough reflex through an increase in substance $P$ secretion. This could prevent the aspiration of foreign materials into the lower respiratory tract, leading to a reduced incidence of pneumonia. However, there are only limited data to support this hypothesis ${ }^{63}$ In elderly people, pneumonia is associated with a higher mortality rate than stroke. Thus, when treating elderly patients to prevent recurrent stroke, cilostazol could be preferentially used if they also have an increased risk of aspiration pneumonia (Figure 3).

\section{Anti-Alzheimer's disease activity of cilostazol}

Alzheimer's disease is a progressive and fatal neurodegenerative disease, with no effective treatment or cure, and it is the main cause of dementia. ${ }^{64}$ The growing number of patients with Alzheimer's disease and the rapidly increasing costs of dementia are now very serious problems. ${ }^{64,65}$ Therefore, effective prophylaxis and treatment of this disease need to be established immediately. In 2009, Arai and Takahashi ${ }^{66}$ reported that a therapy combining cilostazol with the anti-dementia drug donepezil slowed the progression of dementia symptoms in patients with Alzheimer's disease. Subsequently, a series of research articles also described the mitigation of cognitive decline by cilostazol treatment. ${ }^{67,68}$ Currently, an RCT is underway to verify these results. ${ }^{69}$ The potential causative agents of Alzheimer's disease include amyloid $\beta$ peptides and tau proteins. It has been suggested that cilostazol exerts its beneficial effects by reducing amyloid $\beta$ accumulation and tau phosphorylation. ${ }^{70,71}$ Therefore, with the aim of potentially preventing the progression of dementia symptoms, cilostazol may be preferentially selected

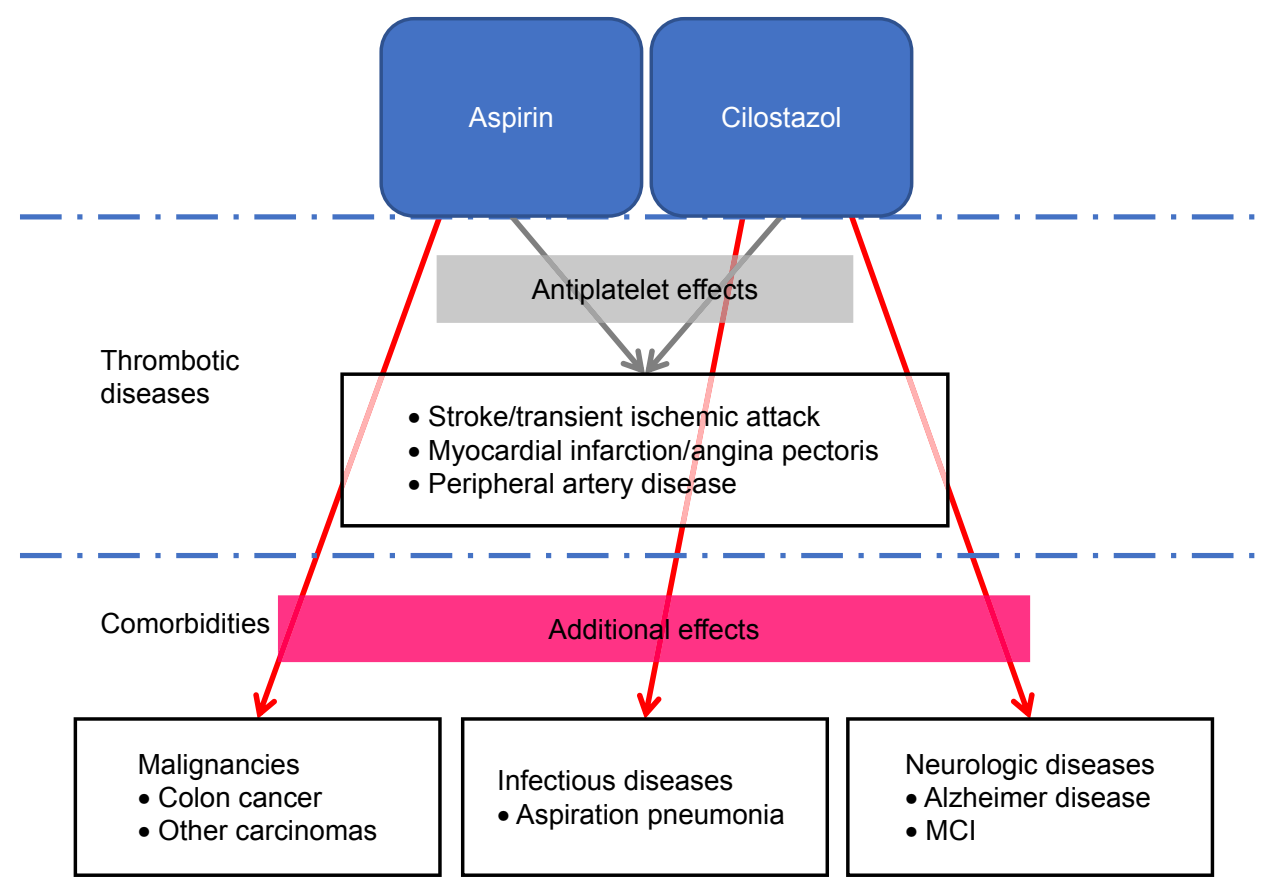

Figure 3 Secondary (additional) effects of antiplatelet agents - beyond the antiplatelet effect.

Note: We can select an antiplatelet agent considering patients' comorbidities, which may be controlled by its secondary (additional) effects beyond the antiplatelet (primary) effect. It is noted that cilostazol should not be used mainly for the secondary benefit but for its antithrombotic effects, because there is insufficient evidence for the additional effects at the present time.

Abbreviation: $\mathrm{MCl}$, mild cognitive impairment. 
in patients with Alzheimer's disease or mild cognitive impairment who need antithrombotic therapy (Figure 3). In fact, when we investigated the effects of a comprehensive intervention for a severe eating and swallowing disorder in older dementia patients, we identified multiple cases where whole-body function, and eating ability were improved by substituting cilostazol for other antiplatelet drugs. ${ }^{72}$

It should be noted that these new findings about the secondary benefits of cilostazol lack sufficient reliable evidence and need more clinical trials to prove its benefits. Therefore, cilostazol should not be used mainly for the secondary benefit, but for its antithrombotic effects. We never recommend prescribing it outside the scope of current insurance coverage.

\section{Cancer preventive effect of aspirin}

In Japan, the total number of deaths from colorectal cancer reaches approximately 50,000 per year. ${ }^{73}$ It is the third leading cause of cancer-related deaths in men, after lung and gastric cancer, and the first in women. ${ }^{73}$ Therefore, routine screening for colorectal cancer is highly recommended, and the development of effective preventive strategies for this cancer is eagerly awaited. Since the 1980s, researchers have suggested the potential anti-colorectal cancer effect of aspirin. For example, a large-scale cohort study started in the United States in 1982 demonstrated that regular use of aspirin is associated with a lower risk of colorectal cancerspecific mortality. ${ }^{74}$ Many similar reports were published from the 1990 s to the 2000s. ${ }^{75-77}$ Subsequently, aspirin was shown to inhibit the progression and recurrence of colorectal cancer and adenomas. ${ }^{78,79}$ Furthermore, aspirin was also proven to reduce colorectal cancer incidence in high-risk patients with, for example, familial adenomatous polyposis and Lynch syndrome, both of which showed significant results. ${ }^{80,81}$ It is now clear that, in addition to colorectal tumors, aspirin can inhibit the development and metastasis of a variety of other epithelial tumors. ${ }^{82,83}$ Based on these results, the US Preventive Services Task Force published a recommendation statement in 2016 regarding the use of aspirin for the prevention of cardiovascular disease and cancer. They recommended initiating aspirin use for the prevention of colorectal cancer in adults aged 50-59 years who have a $10 \%$ or greater 10 -year risk of developing atherosclerotic cardiovascular disease (ASCVD) ${ }^{84}$ A web-based application enabling estimation of 10-year and lifetime risk of ASCVD is available at http://my.americanheart.org/cvriskcalculator. Since the early stages of these studies, researchers have hypothesized that aspirin prevents colorectal cancer progression through the inhibition of cyclooxygenase- $2{ }^{78,85}$ Other aspirin-induced biological reactions, such as the inhibition of nuclear factor (NF)- $\mathrm{B}$ and Toll-like receptor four pathways, are also suggested to play roles in this anti-cancer effect. However, there is as yet no definitive conclusion. Since elderly people have an increased risk of developing cancer as well as thrombosis, we prefer to use aspirin especially in elderly patients with a history of colorectal adenomas or epithelial tumors who require antithrombotic therapy (Figure 3).

\section{Medication adherence in the elderly Management of poor adherence}

Researchers have now identified many conditions (including cognitive impairment) that contribute to poor medication adherence. ${ }^{86-88}$ Therefore, to improve patients' ability to sustain medication adherence, physicians must, whenever possible, develop strategies to either prevent or ameliorate these unfavorable conditions. Medication management is difficult in patients with cerebral infarction or dementia, because these patients have a variety of disabilities, such as cognitive decline, dysphagia, and hemiplegia. The effects of certain oral medications (eg, warfarin) can be monitored using blood tests. For these medications, the measurement of adherence in each patient (ie, the determination of whether each patient takes medications or not) is relatively straightforward. On the other hand, since other medications such as DOACs and antiplatelet drugs cannot affect blood tests, it is difficult to confirm using blood tests whether patients have taken them. From the viewpoint of blood half-life, the effects of warfarin and antiplatelet drugs are not immediately affected by occasional missed doses. In contrast, inadequate adherence to DOACs most likely results in a reduced therapeutic effect within a day. Poor medication adherence also increases the incidence of stroke and the risk of stroke-related mortality. ${ }^{89}$ In a study that investigated the correlation between thrombosis risk and adherence to different DOACs, adherence levels varied significantly between drug types, and lower adherence was significantly associated with a higher incidence of thrombosis..$^{90}$ The following are some of the specific and feasible strategies that can help avoid or improve poor adherence: 1) increase patients' knowledge about the therapeutic importance of their drug regimens; $;{ }^{91}$ 2) select a regimen with less frequent dosing; ${ }^{92,93} 3$ ) when multiple drugs are necessary, simplify medication regimens as much as possible and avoid the need for complex medication management; ${ }^{94}$ 4) use packaging and/or medication reminders; ${ }^{95,96} 5$ ) for patients requiring long-term care, manage medication regimens through daycare or homecare services to achieve a high rate of adherence; ${ }^{19}$ 6) have patients receive pharmacist intervention; ${ }^{97}$ and 
7) for patients with dysphagia, select oral dispersing tablets or crushable tablets. ${ }^{19}$ However, there is only limited evidence available that the above strategies can potentially solve the low-adherence problem. Thus, the issue of improving patient adherence to medications still remains a clinically important subject. ${ }^{98}$ When lowering drug doses or simplifying medication regimens, a range of evidence described in the previous sections can be useful. Patients requiring long-term care can monitor their adherence levels by having remaining dosages examined regularly under the supervision of visiting nurses or pharmacists. Recent approaches to improve adherence include robot-assisted medication management and telemonitoring of drug intake that also provides patient feedback. ${ }^{99}$ However, these approaches have not yet found widespread use in the field of primary care.

\section{Status of DOAC therapy in the elderly}

In recent years, DOACs have rapidly gained wide acceptance in anticoagulation therapy. This is because they do not require strict dose adjustment and coagulation monitoring using blood tests. However, a large proportion of atrial fibrillation patients still do not receive adequate anticoagulation therapy, and, furthermore, this therapy is particularly underused in elderly patients ${ }^{100,101}$ despite the notion that they could gain greater clinical benefits from the treatment (because the risk of thrombosis increases with age more than the risk of bleeding) ${ }^{102}$ In clinical trials conducted under strict medical guidelines, DOACs were associated with a lower risk of hemorrhagic adverse events than warfarin even in elderly patients. These studies also reported differences in bleeding symptoms between different DOACs. ${ }^{103}$ However, the results of clinical trials are not always comparable to those obtained from daily practice where clinical circumstances are diverse. These circumstances include criteria for the initiation of anticoagulation therapy and the selection of anticoagulants, drug doses, patients' compliance with the therapy, and their medication adherence. ${ }^{104}$ Recently, multiple large-scale, realworld analyses reported that there was no clear difference in safety between DOACs and warfarin although the majority of the subjects in these studies were elderly patients (with a mean age in the 70s). ${ }^{105-107}$ However, the results of a meta-analysis of real-world data were similar to those of clinical trials. ${ }^{108}$ There was no difference in the inhibition effect of thrombotic events between DOACs and warfarin, but DOACs were associated with a lower risk of mortality. Moreover, warfarin and DOACs were associated with significantly higher risks of intracranial and gastrointestinal hemorrhages, respectively.

As for medication adherence, the existing results are inconclusive due to the lack of consistent research conditions; one report showed that a DOAC is associated with a higher adherence rate relative to warfarin, while the other found no difference between DOACs and warfarin. ${ }^{109,110}$ Patients who have been taking warfarin for extended periods of time with satisfactory results tend to elect not to switch to a DOAC. ${ }^{111}$ Therefore, there is no reason for physicians to select DOAC therapy for these patients. For patients with poor adherence, physicians may need to reconsider if anticoagulation therapy itself is suitable for them. However, the use of warfarin may allow physicians to effectively determine and optimize dosage regimens for patients at high risk of missing doses. As described above, the efficacy of warfarin is not immediately affected by missed doses. Also, it can be monitored using blood tests. Nevertheless, in actual practice, physicians tend to prescribe a DOAC to low-adherence patients, in whom it is difficult to bring prothrombin time-international normalized ratio values into the therapeutic range with warfarin. ${ }^{112}$ Currently, the clinical outcomes of patients who switch to a DOAC are unknown, and the need to be investigated in the future.

According to the most recent expert consensus document, anticoagulation therapy should be actively administered even in elderly patients, if indicated. For patients without severe renal dysfunction, a direct Xa inhibitor (rivaroxaban, apixaban, or edoxaban), rather than other DOACs, is most highly recommended owing to the favorable safety profiles of these inhibitors. ${ }^{12}$ However, accurate information regarding the risk-benefit balance of the inhibitors is still limited, especially in older patients. Thus, great caution must be exercised when managing these patients. When switching to Xa inhibitors, physicians should always evaluate whether the continuation of ongoing treatment is more beneficial for the patients based on their overall health and medication adherence levels.

\section{Conclusion}

This article reviewed the current problems of antithrombotic therapy caused by a variety of co-existing medical conditions found in elderly patients. Information that can potentially facilitate physicians' decision-making processes was also provided. It was possible to focus on less harmful antithrombotic therapies for elderly patients with comorbidities, but their outcomes, including time to benefit and number of healthy life years gained/gain in healthy life expectancy, could not be discussed. As described above, clinical studies in this field lack a sufficient amount of data collected from elderly patients. Therefore, it is uncertain whether more individualized antithrombotic therapy for elderly patients can improve the prognosis. More clinical studies are now urgently needed in this field. 
The very limited evidence that makes us struggle in daily prescribing practice for elderly patients and shared decisionmaking without definite recommendations. When treating chronic atrial fibrillation in cases with other cardiovascular risks, physicians must estimate, as accurately as possible, whether the benefit of inhibiting thrombotic events outweighs the risk of bleeding before choosing a treatment plan (such as a combination of antithrombotic agents, triplet agents, or concomitant statins). There is only limited information about this disorder. In addition, the evidence for antithrombotic treatment for much older patients, such as octogenarians and nonagenarians, is even more limited. Many clinical challenges remain in daily practice for these patients. Thus, physicians have no choice but to find a treatment plan that is not fully evidence based but is still considered the best strategy for a specific patient. This treatment plan also needs to be a clinically integrated approach that incorporates treatment strategies for co-existing disorders. Furthermore, physicians should try to avoid prescribing too many drugs, thus keeping the medication regimen as simple as possible (preferably, once daily, placed in one dose package). Finally, they should also consider patients' medication adherence history to make sure that they can continue treatment safely and effectively. At this moment, $\mathrm{Xa}$ inhibitors are recommended in elderly patients without renal dysfunction when they begin anticoagulation therapy.

Elderly people have increased risks of both thrombosis and bleeding. Thus, even if they receive the best antithrombotic therapy, they will most likely develop a thrombotic or bleeding event during treatment. On these occasions, it is crucial that physicians clearly explain the reasons for their treatment choices.

\section{Disclosure}

The authors report no conflicts of interest in this work.

\section{References}

1. Hess CN, Norgren L, Ansel GM, et al. A Structured Review of Antithrombotic Therapy in Peripheral Artery Disease With a Focus on Revascularization: A TASC (InterSociety Consensus for the Management of Peripheral Artery Disease) Initiative. Circulation. 2017;135(25): 2534-2555.

2. Gyh L, Collet JP, Caterina R, et al. Antithrombotic therapy in atrial fibrillation associated with valvular heart disease: a joint consensus document from the European Heart Rhythm Association (EHRA) and European Society of Cardiology Working Group on Thrombosis, endorsed by the ESC Working Group on Valvular Heart Disease, Cardiac Arrhythmia Society of Southern Africa (CASSA), Heart Rhythm Society (HRS), Asia Pacific Heart Rhythm Society (APHRS), South African Heart (SA Heart) Association and Sociedad Latinoamericana de Estimulación Cardíaca y Electrofisiología (SOLEACE). Europace. 2017;19(11): 1757-1758.

3. Kirchhof P, Benussi S, Kotecha D, et al. 2016 ESC Guidelines for the management of atrial fibrillation developed in collaboration with EACTS. Europace. 2016;18(11):1609-1678.
4. Kearon C, Akl EA, Ornelas J, et al. Antithrombotic Therapy for VTE Disease: CHEST Guideline and Expert Panel Report. Chest. 2016;149(2):315-352.

5. Carnicelli AP, O'Gara PT, Giugliano RP. Anticoagulation After Heart Valve Replacement or Transcatheter Valve Implantation. Am J Cardiol. 2016;118(9):1419-1426.

6. Patrono C, Morais J, Baigent C, et al. Antiplatelet Agents for the Treatment and Prevention of Coronary Atherothrombosis. J Am Coll Cardiol. 2017;70(14):1760-1776.

7. Kernan WN, Ovbiagele B, Black HR, et al. Guidelines for the Prevention of Stroke in Patients With Stroke and Transient Ischemic Attack: A Guideline for Healthcare Professionals From the American Heart Association/American Stroke Association. Stroke. 2014;45(7):2160-2236.

8. Jaiswal S, Fontanillas P, Flannick J, et al. Age-Related Clonal Hematopoiesis Associated with Adverse Outcomes. $N$ Engl J Med Overseas Ed. 2014;371(26):2488-2498.

9. Jaiswal S, Natarajan P, Silver AJ, et al. Clonal Hematopoiesis and Risk of Atherosclerotic Cardiovascular Disease. N Engl J Med Overseas Ed. 2017;377(2):111-121.

10. Baigent C, Blackwell L, Collins R, et al. Aspirin in the primary and secondary prevention of vascular disease: collaborative meta-analysis of individual participant data from randomised trials. Lancet. 2009; 373(9678):1849-1860.

11. Selak V, Kerr A, Poppe K, et al. Annual Risk of Major Bleeding Among Persons Without Cardiovascular Disease Not Receiving Antiplatelet Therapy. JAMA. 2018;319(24):2507-2520.

12. Andreotti F, Rocca B, Husted S, et al. Antithrombotic therapy in the elderly: expert position paper of the European Society of Cardiology Working Group on Thrombosis. Eur Heart J. 2015;36(46):3238-3249.

13. Kagansky N, Knobler H, Rimon E, Ozer Z, Levy S. Safety of Anticoagulation Therapy in Well-informed Older Patients. Arch Intern Med. 2004;164(18):2044-2050.

14. Rocca B, Husted S. Safety of Antithrombotic Agents in Elderly Patients with Acute Coronary Syndromes. Drugs Aging. 2016;33(4):233-248.

15. Marengoni A, Angleman S, Melis R, et al. Aging withmultimorbidity: A systematic review of the literature. Ageing Res Rev. 2011;10(4):430-439.

16. Barnett K, Mercer SW, Norbury M, Watt G, Wyke S, Guthrie B. Epidemiology of multimorbidity and implications for health care, research, and medical education: a cross-sectional study. The Lancet. 2012;380(9836):37-43.

17. Kojima T, Akishita M, Kameyama Y, et al. High risk of adverse drug reactions in elderly patients taking six or more drugs: Analysis of inpatient database. Geriatr Gerontol Int. 2012;12(4):761-762.

18. Abdelhafiz AH, Wheeldon NM. Risk factors for bleeding during anticoagulation of atrial fibrillation in older and younger patients in clinical practice. Am J Geriatr Pharmacother. 2008;6(1):1-11.

19. The Japan Geriatrics Society. Guidelines for Medical Treatment and its Safety in the Elderly 2015. Tokyo: Medical View Co; 2015.

20. Ikeda Y, Shimada K, Teramoto T, et al. Low-Dose Aspirin for Primary Prevention of Cardiovascular Events in Japanese Patients 60 Years or Older With Atherosclerotic Risk Factors. JAMA. 2014;312(23): 2510-2520.

21. Toyoda K, Yasaka M, Nagata K, et al. Antithrombotic therapy influences location, enlargement, and mortality from intracerebral hemorrhage. The Bleeding with Antithrombotic Therapy (BAT) Retrospective Study. Cerebrovasc Dis. 2009;27(2):151-159.

22. Leon MB, Baim DS, Popma JJ, et al. A Clinical Trial Comparing Three Antithrombotic-Drug Regimens after Coronary-Artery Stenting. N Engl J Med Overseas Ed. 1998;339(23):1665-1671.

23. Natsuaki M, Morimoto T, Yamamoto E, et al. One-year outcome of a prospective trial stopping dual antiplatelet therapy at 3 months after everolimus-eluting cobalt-chromium stent implantation: ShortT and OPtimal duration of Dual AntiPlatelet Therapy after everolimus-eluting cobalt-chromium stent (STOPDAPT) trial. Cardiovasc Interv Ther. 2016; 31(3):196-209.

24. Mauri L, Kereiakes DJ, Yeh RW, et al. Twelve or 30 Months of Dual Antiplatelet Therapy after Drug-Eluting Stents. $N$ Engl J Med Overseas Ed. 2014;371(23):2155-2166. 
25. Ueda H, Kido A, Matsuhisa S, et al. Addition of cilostazol to aspirin therapy for secondary prevention of cardiovascular and cerebrovascular disease in patients undergoing percutaneous coronary intervention: A randomized, open-label trial. Am Heart J. 2016;173:134-142.

26. Dewilde WJM, Oirbans T, Verheugt FWA, et al. Use of clopidogrel with or without aspirin in patients taking oral anticoagulant therapy and undergoing percutaneous coronary intervention: an open-label, randomised, controlled trial. The Lancet. 2013;381(9872):1107-1115.

27. Cannon CP, Bhatt DL, Oldgren J, et al. Dual Antithrombotic Therapy with Dabigatran after PCI in Atrial Fibrillation. $N$ Engl J Med Overseas Ed. 2017;377(16):1513-1524.

28. Zhao Q, Zhu Y, Xu Z, et al. Effect of Ticagrelor Plus Aspirin, Ticagrelor Alone, or Aspirin Alone on Saphenous Vein Graft Patency 1 Year After Coronary Artery Bypass Grafting. JAMA. 2018;319(16):1677-1686.

29. Hiatt WR, Money SR, Brass EP. Long-term safety of cilostazol in patients with peripheral artery disease: The CASTLE study (Cilostazol: A Study in Long-term Effects). J Vasc Surg. 2008;47(2):330-336.

30. Cacoub PP, Bhatt DL, Steg PG, Topol EJ, Creager MA, CHARISMA Investigators. Patients with peripheral arterial disease in the CHARISMA trial. Eur Heart J. 2009;30(2):192-201.

31. Belch JJ, Dormandy J, CASPAR Writing Committee. Results of the randomized, placebo-controlled clopidogrel and acetylsalicylic acid in bypass surgery for peripheral arterial disease (CASPAR) trial. $J$ Vasc Surg. 2010;52(4):825-833.

32. Patel MR, Becker RC, Wojdyla DM, et al. Cardiovascular events in acute coronary syndrome patients with peripheral arterial disease treated with ticagrelor compared with clopidogrel: Data from the PLATO Trial. Eur J Prev Cardiol. 2015;22(6):734-742.

33. Soden PA, Zettervall SL, Ultee KHJ, et al. Dual antiplatelet therapy is associated with prolonged survival after lower extremity revascularization. J Vasc Surg. 2016;64(6):1633-1644.

34. Wang Y, Wang Y, Zhao X, et al. Clopidogrel with Aspirin in Acute Minor Stroke or Transient Ischemic Attack. NEngl J Med Overseas Ed. 2013;369(1):11-19.

35. Diener H-C, Bogousslavsky J, Brass LM, et al. Aspirin and clopidogrel compared with clopidogrel alone after recent ischaemic stroke or transient ischaemic attack in high-risk patients (MATCH): randomised, doubleblind, placebo-controlled trial. The Lancet. 2004;364(9431):331-337.

36. Johnston SC, Easton JD, Farrant M, et al. Clopidogrel and Aspirin in Acute Ischemic Stroke and High-Risk TIA. N Engl J Med. 2018;379:215-225.

37. Bhatt DL, Fox KAA, Hacke W, et al. Clopidogrel and Aspirin versus Aspirin Alone for the Prevention of Atherothrombotic Events. N Engl J Med Overseas Ed. 2006;354(16):1706-1717.

38. Toyoda K, Yasaka M, Iwade K, et al. Dual Antithrombotic Therapy Increases Severe Bleeding Events in Patients With Stroke and Cardiovascular Disease: A Prospective, Multicenter, Observational Study. Stroke. 2008;39(6):1740-1745.

39. Katsanos K, Spiliopoulos S, Saha P, et al. Comparative Efficacy and Safety of Different Antiplatelet Agents for Prevention of Major Cardiovascular Events and Leg Amputations in Patients with Peripheral Arterial Disease: A Systematic Review and Network Meta-Analysis. PLoS One. 2015;10(8):e135692.

40. Lemesle G, Ducrocq G, Elbez Y, et al. Vitamin K antagonists with or without long-term antiplatelet therapy in outpatients with stable coronary artery disease and atrial fibrillation: Association with ischemic and bleeding events. Clin Cardiol. 2017;40(10):932-939.

41. Hansen ML, Sørensen R, Clausen MT, et al. Risk of Bleeding With Single, Dual, or Triple Therapy With Warfarin, Aspirin, and Clopidogrel in Patients With Atrial Fibrillation. Arch Intern Med. 2010;170(16):1433-1441.

42. Eikelboom JW, Connolly SJ, Bosch J, et al. Rivaroxaban with or without Aspirin in Stable Cardiovascular Disease. N Engl J Med Overseas Ed. 2017;377(14):1319-1330.

43. Schatz IJ, Masaki K, Yano K, Chen R, Rodriguez BL, Curb JD. Cholesterol and all-cause mortality in elderly people from the Honolulu Heart Program: a cohort study. The Lancet. 2001;358(9279):351-355.
44. Weverling-Rijnsburger AWE, Blauw GJ, Lagaay AM, Knock DL, Meinders AE, Westendorp RGJ. Total cholesterol and risk of mortality in the oldest old. The Lancet. 1997;350(9085):1119-1123.

45. Vergouwen MDI, de Haan RJ, Vermeulen M, Roos YBWEM. Statin Treatment and the Occurrence of Hemorrhagic Stroke in Patients With a History of Cerebrovascular Disease. Stroke. 2008;39(2):497-502.

46. Shin D, Yoon D, Lim SG, Hong JM, Park RW, Lee JS. Comparison of the Risk of Gastrointestinal Bleeding among Different Statin Exposures with Concomitant Administration of Warfarin: Electronic Health RecordBased Retrospective Cohort Study. PLoS One. 2016;11(7):e0158130.

47. Lee M, Saver JL, Wu YL, et al. Utilization of Statins Beyond the Initial Period After Stroke and 1-Year Risk of Recurrent Stroke. J Am Heart Assoc. 2017;6(8):e005658.

48. Ní Chróinín D, Asplund K, Åsberg S, et al. Statin Therapy and Outcome After Ischemic Stroke: Systematic Review and Meta-Analysis of Observational Studies and Randomized Trials. Stroke. 2013;44(2): $448-456$.

49. Han BH, Sutin D, Williamson JD, et al. Effect of Statin Treatment vs Usual Care on Primary Cardiovascular Prevention Among Older Adults: The ALLHAT-LLT Randomized Clinical Trial. JAMA Intern Med. 2017;177(7):955-965.

50. Montalescot G, Brieger D, Dalby AJ, Park SJ, Mehran R. Duration of Dual Antiplatelet Therapy After Coronary Stenting: A Review of the Evidence. J Am Coll Cardiol. 2015;66(7):832-847.

51. Yeh RW, Secemsky EA, Kereiakes DJ, et al. Development and Validation of a Prediction Rule for Benefit and Harm of Dual Antiplatelet Therapy Beyond 1 Year After Percutaneous Coronary Intervention. JAMA. 2016;315(16):1735-1749.

52. Costa F, van Klaveren D, James S, et al. Derivation and validation of the predicting bleeding complications in patients undergoing stent implantation and subsequent dual antiplatelet therapy (PRECISEDAPT) score: a pooled analysis of individual-patient datasets from clinical trials. The Lancet. 2017;389(10073):1025-1034.

53. Kereiakes DJ, Yeh RW, Massaro JM, et al. DAPT Score Utility for Risk Prediction inPatients With or Without PreviousMyocardial Infarction. J Am Coll Cardiol. 2016;67(21):2492-2502.

54. Piccolo R, Gargiulo G, Franzone A, et al. Use of the Dual-Antiplatelet Therapy Score to Guide Treatment Duration After Percutaneous Coronary Intervention. Ann Intern Med. 2017;167(1):17-25.

55. Yoshikawa Y, Shiomi H, Watanabe H, et al. Validating Utility of Dual Antiplatelet Therapy Score in a Large Pooled Cohort From 3 Japanese Percutaneous Coronary Intervention Studies. Circulation. 2018;137(6): 551-562.

56. Baijens LWJ, Clavé P, Cras P, et al. European Society for Swallowing Disorders - European Union Geriatric Medicine Society white paper: oropharyngeal dysphagia as a geriatric syndrome. Clin Interv Aging. 2016;11:1403-1428.

57. Lanspa MJ, Peyrani P, Wiemken T, Wilson EL, Ramirez JA, Dean NC. Characteristics associated with clinician diagnosis of aspiration pneumonia: A descriptive study of afflicted patients and their outcomes. J Hosp Med. 2015;10(2):90-96.

58. Baine WB, Yu W, Summe JP. Epidemiologic trends in the hospitalization of elderly Medicare patients for pneumonia, 1991-1998. Am J Public Health. 2001;91(7):1121-1123.

59. Yamaya M, Yanai M, Ohrui T, Arai H, Sekizawa K, Sasaki H. Antithrombotic Therapy for Prevention of Pneumonia. J Am Geriatr Soc. 2001;49(5):687-688.

60. Shinohara Y. Antiplatelet Cilostazol Is Effective in the Prevention of Pneumonia in Ischemic Stroke Patients in the Chronic Stage. Cerebrovasc Dis. 2006;22(1):57-60.

61. Osawa A, Maeshima S, Tanahashi N. Efficacy of Cilostazol in Preventing Aspiration Pneumonia in Acute Cerebral Infarction. Journal of Stroke and Cerebrovascular Diseases. 2013;22(6):857-861.

62. The Japan Stroke Society. Japanese Guidelines for the Management of Stroke 2015. Tokyo: Kyowa Kikaku Corp; 2015. In Japanese. 
63. Abe A, Nishiyama Y, Hagiwara H, et al. Administration of Cilostazol, an Antiplatelet, to Patients with Acute-stage Cerebral Infarction and Its Effects on Plasma Substance P Level and Latent Time of Swallowing Reflex. J Nippon Med Sch. 2013;80(1):50-56.

64. Winblad B, Amouyel P, Andrieu S, et al. Defeating Alzheimer's disease and other dementias: a priority for European science and society. Lancet Neurol. 2016;15(5):455-532.

65. Prince M, Bryce R, Albanese E, Wimo A, Ribeiro W, Ferri CP. The global prevalence of dementia: A systematic review and metaanalysis. Alzheimer's \& Dementia. 2013;9(1):63-75.

66. Arai H, Takahashi T. A Combination Therapy of Donepezil and Cilostazol for Patients With Moderate Alzheimer Disease: Pilot Follow-Up Study. The American Journal of Geriatric Psychiatry. 2009;17(4): 353-354.

67. Taguchi A, Takata Y, Ihara M, et al. Cilostazol improves cognitive function in patients with mild cognitive impairment: a retrospective analysis. Psychogeriatrics. 2013;13(3):164-169.

68. Hishikawa N, Fukui Y, Sato K, Ohta Y, Yamashita T, Abe K. Comprehensive effects of galantamine and cilostazol combination therapy on patients with Alzheimer's disease with asymptomatic lacunar infarction. Geriatr Gerontol Int. 2017;17(10):1384-1391.

69. Saito S, Kojima S, Oishi N, et al. A multicenter, randomized, placebocontrolled trial for cilostazol in patients with mild cognitive impairment: The COMCID study protocol. Alzheimers Dement. 2016;2(4): 250-257.

70. Park SH, Kim JH, Bae SS, et al. Protective effect of the phosphodiesterase III inhibitor cilostazol on amyloid $\beta$-induced cognitive deficits associated with decreased amyloid $\beta$ accumulation. Biochem Biophys Res Commun. 2011;408(4):602-608.

71. Lee HR, Shin HK, Park SY, et al. Attenuation of $\beta$-amyloid-induced tauopathy via activation of CK2 $\alpha /$ SIRT1: Targeting for cilostazol. J Neurosci Res. 2014;92(2):206-217.

72. Arahata M, Oura M, Tomiyama Y, et al. A comprehensive intervention following the clinical pathway of eating and swallowing disorder in the elderly with dementia: historically controlled study. BMC Geriatr. 2017;17(1):146.

73. Director-General For Statistics And Information Policy [webpage on the Internet]. Vital Statistics in Japan. Trend up to 2015. Tokyo: Ministry of Health Labour and Welfare; 2017. Available from: www.mhlw.go.jp/ toukei/list/81-1a.html. Accessed May 20, 2018.

74. Thun MJ, Namboodiri MM, Heath CW. Aspirin Use and Reduced Risk of Fatal Colon Cancer. N Engl J Med Overseas Ed. 1991;325(23): 1593-1596.

75. Chan AT, Giovannucci EL, Meyerhardt JA, Schernhammer ES, Curhan GC, Fuchs CS. Long-term Use of Aspirin and Nonsteroidal Anti-inflammatory Drugs and Risk of Colorectal Cancer. JAMA. 2005; 294(8):914-923

76. Chan AT, Giovannucci EL, Meyerhardt JA, Schernhammer ES, Wu K, Fuchs CS. Aspirin Dose and Duration of Use and Risk of Colorectal Cancer in Men. Gastroenterology. 2008;134(1):21-28.

77. Rothwell PM, Wilson M, Elwin C-E, et al. Long-term effect of aspirin on colorectal cancer incidence and mortality: 20-year follow-up of five randomised trials. The Lancet. 2010;376(9754):1741-1750.

78. Chan AT, Ogino S, Fuchs CS. Aspirin use and survival after diagnosis of colorectal cancer. JAMA. 2009;302(6):649-658.

79. Cole BF, Logan RF, Halabi S, et al. Aspirin for the Chemoprevention of Colorectal Adenomas: Meta-analysis of the Randomized Trials. JNCI: Journal of the National Cancer Institute. 2009;101(4):256-266.

80. Burn J, Gerdes A-M, Macrae F, et al. Long-term effect of aspirin on cancer risk in carriers of hereditary colorectal cancer: an analysis from the CAPP2 randomised controlled trial. The Lancet. 2011;378(9809):2081-2087.

81. Ishikawa H, Wakabayashi K, Suzuki S, et al. Preventive effects of low-dose aspirin on colorectal adenoma growth in patients with familial adenomatous polyposis: double-blind, randomized clinical trial. Cancer Med. 2013;2(1):50-56.
82. Rothwell PM, Fowkes FGR, Belch JFF, Ogawa H, Warlow CP, Meade TW. Effect of daily aspirin on long-term risk of death due to cancer: analysis of individual patient data from randomised trials. The Lancet. 2011;377(9759):31-41.

83. Algra AM, Rothwell PM. Effects of regular aspirin on long-term cancer incidence and metastasis: a systematic comparison of evidence from observational studies versus randomised trials. Lancet Oncol. 2012;13(5):518-527.

84. Bibbins-Domingo K, U.S. Preventive Services Task Force. Aspirin Use for the Primary Prevention of Cardiovascular Disease and Colorectal Cancer: U.S. Preventive Services Task Force Recommendation Statement. Ann Intern Med. 2016;164(12):836-845.

85. Chan AT, Ogino S, Fuchs CS. Aspirin and the Risk of Colorectal Cancer in Relation to the Expression of COX-2. NEnglJMed Overseas Ed. 2007; 356(21):2131-2142.

86. Osterberg L, Blaschke T. Adherence to Medication. $N$ Engl J Med Overseas Ed. 2005;353(5):487-497.

87. Pasina L, Brucato AL, Falcone C, et al. Medication Non-Adherence Among Elderly Patients Newly Discharged and Receiving Polypharmacy. Drugs Aging. 2014;31(4):283-289.

88. Yap AF, Thirumoorthy T, Kwan YH. Systematic review of the barriers affecting medication adherence in older adults. Geriatr Gerontol Int 2016;16(10):1093-1101.

89. Herttua K, Tabák AG, Martikainen P, Vahtera J, Kivimäki M. Adherence to antihypertensive therapy prior to the first presentation of stroke in hypertensive adults: population-based study. Eur Heart J. 2013;34(38): 2933-2939.

90. Borne RT, O'Donnell C, Turakhia MP, et al. Adherence and outcomes to direct oral anticoagulants among patients with atrial fibrillation: findings from the veterans health administration. BMC Cardiovasc Disord. 2017;17(1):236.

91. Bazargan M, Smith J, Yazdanshenas H, Movassaghi M, Martins D, Orum $\mathrm{G}$. Non-adherence to medication regimens among older AfricanAmerican adults. BMC Geriatr. 2017;17(1):163.

92. Claxton AJ, Cramer J, Pierce C. A systematic review of the associations between dose regimens and medication compliance. Clin Ther. 2001;23(8):1296-1310.

93. Alberts MJ, Peacock WF, Fields LE, et al. Association between onceand twice-daily direct oral anticoagulant adherence in nonvalvular atrial fibrillation patients and rates of ischemic stroke. Int J Cardiol. 2016;215:11-13.

94. Wimmer BC, Cross AJ, Jokanovic N, et al. Clinical Outcomes Associated with Medication Regimen Complexity in Older People: A Systematic Review. J Am Geriatr Soc. 2017;65(4):747-753.

95. Zedler BK, Kakad P, Colilla S, Murrelle L, Shah NR. Does Packaging with a Calendar Feature Improve Adherence to Self-Administered Medication for Long-Term Use? A Systematic Review. Clin Ther. 2011; 33(1):62-73.

96. Conn VS, Ruppar TM, Chan KC, Dunbar-Jacob J, Pepper GA, de Geest S. Packaging interventions to increase medication adherence: systematic review and meta-analysis. Curr Med Res Opin. 2015;31(1): 145-160.

97. Murray MD, Young J, Hoke S, et al. Pharmacist Intervention to Improve Medication Adherence in Heart Failure. Ann Intern Med. 2007; 146(10):714-725.

98. Nieuwlaat R, Wilczynski N, Navarro T, et al. Interventions for enhancing medication adherence. Cochrane Database Syst Rev. 2014;11: CD000011.

99. Desteghe L, Vijgen J, Koopman P, et al. Telemonitoring-based feedback improves adherence to non-vitamin $\mathrm{K}$ antagonist oral anticoagulants intake in patients with atrial fibrillation. Eur Heart J. 2018;39(16) 1394-1403.

100. Mochalina N, Jöud A, Carlsson M, et al. Antithrombotic therapy in patients with non-valvular atrial fibrillation in Southern Sweden: A population-based cohort study. Thromb Res. 2016;140:94-99. 
101. Admassie E, Chalmers L, Bereznicki LR. Changes in Oral Anticoagulant Prescribing for Stroke Prevention in Patients With Atrial Fibrillation. Am J Cardiol. 2017;120(7):1133-1138.

102. Patti G, Lucerna M, Pecen L, et al. Thromboembolic Risk, Bleeding Outcomes and Effect of Different Antithrombotic Strategies in Very Elderly Patients With Atrial Fibrillation: A Sub-Analysis From the PREFER in AF (PREvention oF Thromboembolic Events-European Registry in Atrial Fibrillation). J Am Heart Assoc. 2017;6(7): e005657pii:e005657.

103. Sharma M, Cornelius VR, Patel JP, Davies JG, Molokhia M. Efficacy and Harms of Direct Oral Anticoagulants in the Elderly for Stroke Prevention in Atrial Fibrillation and Secondary Prevention of Venous Thromboembolism: Systematic Review and Meta-Analysis. Circulation. 2015;132(3):194-204.

104. Potpara TS, Lip GY. Postapproval Observational Studies of NonVitamin K Antagonist Oral Anticoagulants in Atrial Fibrillation. JAMA. 2017;317(11):1115-1116.

105. Coleman CI, Peacock WF, Bunz TJ, Alberts MJ. Effectiveness and Safety of Apixaban, Dabigatran, and Rivaroxaban Versus Warfarin in Patients With Nonvalvular Atrial Fibrillation and Previous Stroke or Transient Ischemic Attack. Stroke. 2017;48(8):2142-2149.

106. Yamashita Y, Uozumi R, Hamatani Y, et al. Current Status and Outcomes of Direct Oral Anticoagulant Use in Real-World Atrial Fibrillation Patients-Fushimi AF Registry. Circ J. 2017;81(9):1278-1285.

107. Jun M, Lix LM, Durand M, et al. Comparative safety of direct oral anticoagulants and warfarin in venous thromboembolism: multicentre, population based, observational study. BMJ. 2017;359:j4323.
108. Ntaios G, Papavasileiou V, Makaritsis K, et al. Real-World Setting Comparison of Nonvitamin-K Antagonist Oral Anticoagulants Versus Vitamin-K Antagonists for Stroke Prevention in Atrial Fibrillation: A Systematic Review and Meta-Analysis. Stroke. 2017; 48(9):2494-2503.

109. Mchorney CA, Ashton V, Laliberté F, et al. Adherence to Rivaroxaban Compared with Other Oral Anticoagulant Agents Among Patients with Nonvalvular Atrial Fibrillation. J Manag Care Spec Pharm. 2017; 23(9):980-988.

110. Keita I, Aubin-Auger I, Lalanne C, et al. Assessment of quality of life, satisfaction with anticoagulation therapy, and adherence to treatment in patients receiving long-course vitamin $\mathrm{K}$ antagonists or direct oral anticoagulants for venous thromboembolism. Patient Prefer Adherence. 2017;11:1625-1634.

111. Ikeda T, Yasaka M, Kida M, Imura M. A survey of reasons for continuing warfarin therapy in the era of direct oral anticoagulants in Japanese patients with atrial fibrillation: the SELECT study. Patient Prefer Adherence. 2018;12:135-143.

112. Hirano T, Kaneko H, Mishina S, Wang F, Morita S. Suboptimal Anticoagulant Management in Japanese Patients with Nonvalvular Atrial Fibrillation Receiving Warfarin for Stroke Prevention. J Stroke Cerebrovasc Dis. 2017;26(10):2102-2110.
Clinical Interventions in Aging

\section{Publish your work in this journal}

Clinical Interventions in Aging is an international, peer-reviewed journal focusing on evidence-based reports on the value or lack thereof of treatments intended to prevent or delay the onset of maladaptive correlates of aging in human beings. This journal is indexed on PubMed Central, MedLine,

\section{Dovepress}

CAS, Scopus and the Elsevier Bibliographic databases. The manuscript management system is completely online and includes a very quick and fair peer-review system, which is all easy to use. Visit http://www.dovepress. com/testimonials.php to read real quotes from published authors. 